\title{
Deformed wing virus is not related to honey bees' aggressiveness
} \section{Agnès Rortais ${ }^{1}$, Diana Tentcheva ${ }^{2}$, Alexandros Papachristoforou ${ }^{3}$, Laurent Gauthier*2, Gérard Arnold1, Marc Edouard Colin² and Max Bergoin²}

\author{
Address: ${ }^{1}$ Laboratoire Populations, Génétique, Evolution CNRS, UPR 9034, avenue de la Terrasse, 91198 Gif-sur-Yvette -, France, ${ }^{2}$ Laboratoire de \\ Pathologie Comparée des Invertébrés EPHE, UMR 1231, Biologie Intégrative et Virologie des Insectes INRA, Université Montpellier II, Place \\ Bataillon, 34095 Montpellier -, France and ${ }^{3}$ Laboratory of Apiculture-Sericulture, School of Agriculture, Aristotle University of Thessaloniki -, \\ Greece \\ Email: Agnès Rortais - rortais@legs.cnrs-gif.fr; Diana Tentcheva - dianatent@yahoo.fr; Alexandros Papachristoforou - alpapa@agro.auth.gr; \\ Laurent Gauthier* - gauthier@univ-montp2.fr; Gérard Arnold - Gerard.Arnold@legs.cnrs-gif.fr; Marc Edouard Colin - colinme@ensam.inra.fr; \\ Max Bergoin - bergoin@ensam.inra.fr \\ * Corresponding author
}

Published: 30 August 2006

Virology Journal 2006, 3:61 doi:I0.1186/1743-422X-3-61

This article is available from: http://www.virologyj.com/content/3/I/6I

(C) 2006 Rortais et al; licensee BioMed Central Ltd.

This is an Open Access article distributed under the terms of the Creative Commons Attribution License (http://creativecommons.org/licenses/by/2.0), which permits unrestricted use, distribution, and reproduction in any medium, provided the original work is properly cited.
Received: 24 March 2006

Accepted: 30 August 2006

\begin{abstract}
Guards of Cyprian honey bee colonies, Apis mellifera cypria, display a great defensive behaviour against hornets' attacks. The deformed wing virus (DWV) and the kakugo virus (KV) genomes are very similar, but unlike $K V$, the presence of $D W V$ is not related to honey bees' aggressiveness. This discrepancy is further discussed.
\end{abstract}

\section{Findings}

Temporal polyethism is widespread among social hymenopteran, and particularly in the honey bee Apis mellifera $\mathrm{L}$. $[1,2]$. The behavioural shifts that occur as a worker ages are associated with physiological changes such as variation in juvenile hormone titres in the insect haemolymph [3] or variation in octopamine levels in the bee head [4]. As the expression patterns of the mRNA in honey bee brains predict behavioural changes [5], one can expect that viral infections located in heads might have profound effects on the behaviour of bees. Until now, only one insect virus - namely the sacbrood virus (SBV), has been found to modify workers tasks. SBV infected adults were found to forage earlier in life than controls, and most infected foragers failed in collecting pollen; these effects were attributed to physiological changes due to viral infection $[6,7]$. Recently, the kakugo virus (KV), which was only detected in the brain of aggressive workers of Italian bees by real-time PCR, was suggested to trigger behavioural changes in honey bees [8].
Among the 13 honey bee viruses described in Apis mellifera L. [9], the deformed wing virus (DWV) is one of the most common [10-12]. DWV belongs to the novel family of the Iflaviridae and its genome consists of a single strand positive RNA encompassing a single open reading frame which codes for both structural and non structural polypeptides [13]. DWV is suspected to induce typical injuries on the wings of infected workers, mostly in those heavily infested with the ectoparasite Varroa destructor [9]. In honey bee colonies, association of DWV with mite infestations has been largely documented [10,14-16]. DWV was further evidenced in different worker, queen and drone organs by quantitative RT-PCR and in situ hybridisation $[17,18]$ indicating that it might have a considerable degree of tissue specificity.

The DWV and KV sequences show a great homology (98\%, at the nucleotide level). Considering this, we tested whether DWV, like KV, is related to honey bees' aggressiveness by comparing DWV RNA loads in aggressive 
(guards) versus non aggressive honey bees (emerging bees, nurses and foragers) issued from several colonies of Apis mellifera cypria, a race that exhibits a great defensive behaviour against the hornet Vespa orientalis [19].

Honey bees (Apis mellifera cypria) were collected in an apiary located in the southern part of Cyprus in three sampling times (October and November 2004, and April 2005). For each sampling time, 10 guards and 10 nurses were collected in 5 colonies (total of 300 individuals), and during the last sampling, 5 more colonies and 2 other temporal castes (emerging bees and foragers) were sampled (total of 100 additional individuals). Emerging bees were collected directly in brood cells and nurses on brood combs. Guards were trapped on flight boards using a living hornet as lure, and foragers were collected when returning to the hive with pollen pellets. All samples were stored in ethanol (95\%) and DWV RNA loads were determined by quantitative RT-PCR, using a standardised protocol [16]. Each analysis was representative of a pool of 10 individuals and heads were analysed separately from thoraxes and abdomens.

DWV RNA loads recorded in the different bee samples were compared using the SigmaStat 2.03 software (Systat). A Mann-Whitney Rank Sum Test showed no statistical differences between nurses and guards collected during the three sampling times (in bodies, guards versus nurses: $\mathrm{T}=294.500, \mathrm{P}=0.428$; in heads, guards versus nurses: $\mathrm{T}=350.000, \mathrm{P}=0.820$ ). Likewise, the DWV RNA loads recorded in the 10 colonies collected in April 2004 showed no statistical differences, neither among the four temporal castes nor between body parts (ANOVA on ranks: $\mathrm{H}=1.541 ; \mathrm{df}=3 ; \mathrm{P}=0.673$ ). Data are presented on Figure 1.

For comparisons, DWV RNA loads were determined in nurses and guards using KV [8] and DWV [16] primers. Each couple of primers displayed similar PCR efficiency (DWV: $\mathrm{y}=-3.26 \mathrm{x}+17.12 ; \mathrm{R}^{2}=0.998-\mathrm{KV}: \mathrm{y}=-3.24 \mathrm{x}+$ $17.75 ; \mathrm{R}^{2}=0.990$ ), but never allowed to distinguish different viral populations according to the standard error generated by the technique [16].

In this paper, we showed that infection of A. m. cypria by DWV is common in all colonies and that there are no significant differences among temporal castes and body parts. Thus, despite their high genome homology, KV and DWV display distinct biological patterns. In order to explain such discrepancies, several hypotheses are proposed.

Small changes in the amino acid composition of DWV and KV might be sufficient to modify their viral tissue tropism such that one variant, the $\mathrm{KV}$, specifically targets the
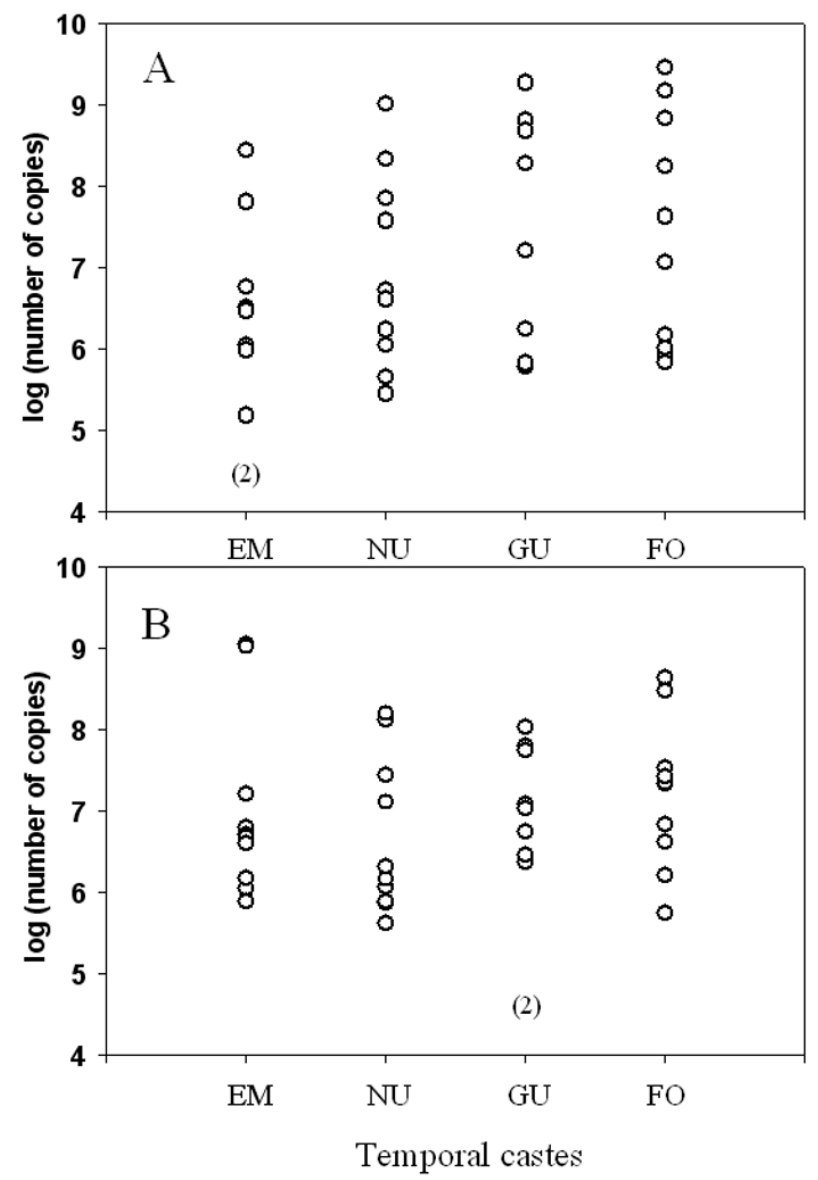

Figure I

DWV RNA values recorded in the head (A) and body (B) of bees issued from 10 colonies of $A$. mellifera cypria in April 2004. EM: emerging bees; NU: nurses; GU: guards; FO: foragers. Results are representative of 10 individuals and are expressed as mean of triplicates in number of DWV RNA copies per body part (head or thorax and abdomen). The number of negative DWV samples is indicated into brackets.

brain of the honey bee and be responsible for the observed behavioural changes. The genome of these two viruses show a higher polymorphism in the putative leader polyprotein coding region which has already been found to be associated with viral pathogenesis [13].

The behaviour of these two viruses may also vary with the origin of honeybees (e.g. race, colony). While KV and DWV are detected in the heads of asymptomatic Italian (A. m. ligustica) [8] and Cyprian (A. m. cypria) honeybees, respectively, DWV is not detected in the head of asymptomatic German (A. m. carnica) honeybees [20]. According to the race and/or the origin of colonies, KV and DWV may not have the same viral tissue tropism. However, given that 10 colonies of A. m. cypria honeybees were ana- 
lysed whereas only two colonies of $A$. $m$. ligustica were analysed for the study of KV [8], one cannot exclude that the effects of inter-colonial variations may have been less significant for the detection of KV than for the detection of DWV. This sampling bias poses a serious flaw on the significance of the results previously found [8].

Given the high degree of identity between DWV and KV sequences, it is difficult to design primers specific enough to distinguish between the sequences of the two viruses from a single one bee population. DWV was previously detected by PCR in approximately $60 \%$ of colonies [11] suggesting that KV must be absent from $40 \%$ of colonies. However, all colonies have guards which aggressivity vary with environmental conditions such as humidity, heat, and nectar availability [21,22]; Thus, it seems very unlikely that the presence of KV or DWV has any relation with the aggressiveness of guards. The absence of any significant relation between the presence of DWV and the aggressiveness of Cyprian honeybees supports this assumption. More likely, the intensity of the defensive reaction depends on interactions between individuals and between environmental and genetic effects (see [23] for a review).

There is now a strong evidence that DWV could spread out among colonies independently of mites infestation, that is by food secretions from nurses to larvae or from queen to workers [18]. The mite, Varroa destructor, is responsible for the spreading of DWV in all bee tissues by haemolymph spoliation and reactivation of viral infections [15]. Thus, one can assume that in the absence of the mite, DWV and KV might specifically target bee heads where they further concentrate. Therefore, it is possible that the data recorded by Fujiyuki et al. (2004) and those presented in this study reflect different levels of mite infestation among colonies. RNA viruses are generally distributed as quasispecies [24], representing a population made of a cloud of genetic variants. Recently, this population genetic diversity was found to determine pathogenesis through cooperative interactions [25]. It would be challenging to understand why some honey bees colonies (e.g. Cyprian and Italian honey bees) might host particular types of viruses (e.g. DWV and KV) with specific tropisms and different levels of pathogenicity. In that, assuming that DWV replicates in $V$. destructor, one can hypothesizes that mites can influence the genetic outcome of viral populations as it has recently been suggested [20].

\section{Competing interests}

The author(s) declare that they have no competing interests.

\section{Authors' contributions}

AR and DT contributed equally to this work. AR and AP performed field experiments. DT did the quantitative PCR analysis. LG and AR planed the experiments and wrote the manuscript. MEC did the statistical analysis. GA, MEC and $\mathrm{MB}$ contributed to the design of the experiments and revised the manuscript. All authors read and approved the final manuscript.

\section{Acknowledgements}

We thank Mr Varnava, President of the Cypriot Beekeepers Union, for his collaboration and support, and Mr Kallenos for offering 40 colonies for the experiment. This work was supported by the EC, the French Ministry of Agriculture (CE/I22 I/97), EGIDE, and the Research Promotion Foundation of Cyprus.

\section{References}

I. Robinson GE: Regulation of division of labor in insect societies. Ann Rev Entomol 1992, 37:637-665.

2. Winston ML: The biology of the honey bee. Edited by: Press HU. Cambridge, ; 1987.

3. Robinson GE, Page RE, Strambi C, Strambi A: Hormonal and genetic control of behavioral integration in honey bee colonies. Science 1989, 246:109-II2.

4. Wagener-Hulme C, Kuehn JC, Schultz DJ, Robinson GE: Biogenic amines and division of labor in honey bee colonies. J Comp Physiol 1999, 184:47I-479.

5. Whitfield CW, Cziko AM, Robinson GE: Gene expression profiles in the brain predict behavior in individual honey bees. Science 2003, 302:296-299.

6. Bailey L, Fernando EFW: Effects of sacbrood virus on adults honey-bees. Ann Appl Biol 1972, 72:27-35.

7. Anderson DL, Giacon H: Reduced Pollen Collection by HoneyBee (Hymenoptera, Apidae) Colonies Infected with Nosema-Apis and Sacbrood Virus. Journal of Economic Entomology 1992, 85:47-5I.

8. Fujiyuki T, Takeuchi H, Ono M, Ohka S, Sasaki T, Nomoto A, Kubo $\mathrm{T}$ : Novel insect picorna-like virus identified in the brains of aggressive worker honeybees. J Virol 2004, 78: 1093-I 100.

9. Bailey L, Ball BV: Honey Bee Pathology. 2nd edition. London, Harcourt Brace Jovanovich; 1991:193.

10. Nordstrom S, Fries I, Aarhus A, Hansen H, Korpela S: Virus infections in Nordic honey bee colonies with no, low or severe Varroa jacobsoni infestations. Apidologie 1999, 30:475-484.

II. Tentcheva D, Gauthier L, Zappulla N, Dainat B, Cousserans F, Colin $M E$, Bergoin M: Prevalence and seasonal variations of six bee viruses in Apis mellifera L. and Varroa destructor mite populations in France. Appl Environ Microbiol 2004, 70:7185-7191.

12. Allen $M$, Ball $B$ : The incidence and world distribution of honey bee viruses. Bee World 1996, 77:141-162.

13. Lanzi G, de Miranda JR, Boniotti MB, Cameron CE, Lavazza A, Capucci L, Camazine SM, Rossi C: Molecular and biological characterization of deformed wing virus of honeybees (Apis mellifera L.). J Virol 2006, 80:4998-5009.

14. Bowen-Walker PL, Martin SJ, Gunn A: The transmission of deformed wing virus between honeybees (Apis mellifera L.) by the ectoparasitic mite varroa jacobsoni Oud. I Invertebr Pathol 1999, 73:101-106.

15. Shen M, Yang X, Cox-Foster D, Cui L: The role of varroa mites in infections of Kashmir bee virus (KBV) and deformed wing virus (DWV) in honey bees. Virology 2005, 342: |4|-| 49.

16. Tentcheva D, Gauthier L, Bagny L, Fievet J, Dainat B, Cousserans F, Colin ME, Bergoin M: Comparative analysis of deformed wing virus (DWV) RNA in Apis mellifera L. and Varroa destructor. Apidologie 2006, 37:4I-50.

17. Fievet J, Tentcheva D, Gauthier L, de Miranda JR, Cousserans F, Colin $M E$, Bergoin M: Localization of deformed wing virus infection in queen and drone Apis mellifera L. Virology Journal 2006, 3: I-5.

18. Chen YP, Pettis JS, Collins A, Feldlaufer MF: Prevalence and transmission of honeybee viruses. Appl Environ Microbiol 2006, 72:606-6II. 
19. Papachristophorou A, Rortais A, Arnold G, loannides I, Séraphides N, Garnery L, Thrasyvolou A: Defensive behaviour of Apis mellifera cypria against the hornet Vespa orientalis.: ; Dublin, Ireland. ; 2005.

20. Yue $C$, Genersch E: RT-PCR analysis of Deformed wing virus in honeybees (Apis mellifera) and mites (Varroa destructor). J Gen Virol 2005, 86:3419-3424.

21. Guzman-Novoa E, Page RE: Selective breeding of honey bees (Hymenoptera: Apidae) in Africanized areas. J Econ Entomol 1999, 92:521-525.

22. Southwick EE, Moritz RFA: Effects of meteorological factors on defensive behavior of honey bee. Int J Biometeorol 1987, 3 I:259-265.

23. Breed MD, Guzman-Novoa E, Hunt G: Defensive behavior of honey bees: organization, genetics, and comparisons with other bees. Annu Rev Entomol 2004, 49:27I-298.

24. Eigen M: On the nature of virus quasispecies. Trends Microbiol 1996, 4:216-217.

25. Vignuzzi M, Stone JK, Arnold JJ, Cameron CE, Andino R: Quasispecies diversity determines pathogenesis through cooperative interactions in a viral population. Nature 2005, 4:344-348.

Publish with Bio Med Central and every scientist can read your work free of charge

"BioMed Central will be the most significant development for disseminating the results of biomedical research in our lifetime. "

Sir Paul Nurse, Cancer Research UK

Your research papers will be:

- available free of charge to the entire biomedical community

- peer reviewed and published immediately upon acceptance

- cited in PubMed and archived on PubMed Central

- yours - you keep the copyright

Submit your manuscript here:

http://www.biomedcentral.com/info/publishing_adv.asp 